\title{
COUNTRY RISK ASSESSMENT FOR THE UNITED KINGDOM
}

\author{
Hussein Ahmad Bataineh ${ }^{1 \mathrm{i}}$, \\ Sulaiman Humaid Al Harthy², \\ Raqiya Ali Al Balushi ${ }^{3}$, \\ Ahmad Omar Albesisi ${ }^{4}$ \\ ${ }^{1}$ Research Scholar, \\ Finance Department, \\ Jordan University, \\ Amman, Jordan \\ 2Senior Islamic Banking Analyst, \\ Central Bank of Oman, \\ Oman \\ ${ }^{3}$ Internal Auditor, \\ Bank Muscat, \\ Oman \\ ${ }^{4}$ Human Resources Department, \\ Alrajhi Bank, \\ Saudi Arabia
}

\begin{abstract}
:
The study aims to make risk assessment of investment in the United Kingdom so as to open a new branch of a big bank in United Arab Emirate. The findings of the risk assessment recommended to establish the new branch in the UK basing on diverse reasons. Firstly, according to the international monitory fund report, the GDP of the United Kingdom will increase from the financial year 2018 through the financial year 2022. The economy will advance and widen. Plus, the growth in GDP indicate that all sector in economy including the banking sector will also develop. Secondly, according to the UK office Budget Responsibility (ORB) projections, the UK interest rate will rise in the coming four financial years that will surely be reflected on the increase of profitability. Thirdly, the inflation rate in the UK will decrease in the coming four years, which has positive effects on the banking sectors because inflation rate leads to low costs of products and services. Additionally, the GDP per capital of the UK rise in the coming four fiscal years which is healthy for banking sector to be highly productive and profitable. More importantly the population of the UK will increase in the coming four years, which is favourable to the banking sector this means that the number of will increase. Moreover, the bank of England allows all the commercial banks in the country. Another reason that
\end{abstract}

i Correspondence: email hussainsalbataineh@gmail.com 
encourage investing in the $\mathrm{UK}$ is the advancement in technology. Besides, the most important reason encourage investment in the UK is the country's system of governance that is a democratic system of leadership that does not hinders private investors unless they violate law. The researchers conclude that they recommend the decision to open the new bank in the UK. Since the benefits supersede the costs.

JEL: E22; F21; G21

Keywords: country risk assessment, investment, economic profile

\section{Introduction}

We are consultant company has been selected by big bank in UAE to perform risk assessment of UK in order to open new operation in UK ether as branch or acquire a subsidiary. The United Kingdom economy which is the world sixth biggest economy grew by $1.7 \%$ in the financial year 2017, faintly less than in FY2016 (+1.8). Essentially, projections for 2019 and 2018 presume growth to alleviate at about 1.5\%. The nation's economy is influenced by the doubts that surround the ongoing Brexit consultations. The UK chose to quit the EU in June 2016. Since then, the UK regime has been negotiating the terms and conditions of the state's exit. Based on the United Kingdom risk assessment, the establishment of The New Bank in the United Kingdom is recommend based on diverse reasons. Firstly, according to the international monetary fund report, the GDP of the United Kingdom will increase from the financial year 2018 through the fiscal year 2022. That projection is favourable for investment it implies the economy will advance and widen; hence, increasing the aggregate demand for money (loans). Plus, the growth in GDP indicates that all sectors of the economy, including the banking sector, will also develop. Therefore, if The New Bank's owners decide to invest in the UK, their business is more likely to grow and develop in the coming four years.

Secondly, according to the UK Office for Budget Responsibility (OBR) projections, the UK's interest rate will rise in the coming four financial years, which is healthy for the players in the banking sector. That is because the rise in interest rate increases the bank earnings from loans; hence, increasing their profitability. Simply put, the interest rate is the price of borrowing loan, so, increasing it is basically boosting the revenues and profit margin for the commercial banks. Therefore, if The New Bank's owners proceed to invest in the United Kingdom, they are more likely to record increasing profitability in the coming four financial years. Thirdly, the inflation rate in the United Kingdom will decrease in the coming four years, which has some positive effects on the players in the banking sector. That is because low inflation rate results in low costs of products and services (including employees' salaries and wages); hence, banks make more profits due to reduced cost of productions. Therefore, if the owners of The New Bank invest in the United Kingdom, they are more likely to incur increasing profitability in the coming four years. 
Additionally, the GDP per capita of the United Kingdom rise in the coming four fiscal years, which is healthy for the banking sector. That is because an increase in GDP per Capita implies that the major sectors of the economy are highly productive and profitable, (including the players in the banking sector). So, if The New Bank's owners proceed to venture in the United Kingdom the chances of their business to grow in the coming years will be high.

Also, the population of the United Kingdom will increase in the coming four years, which is favourable for the banking sector. That is because an increase in the population size in an economy implies a rise in the number of potential customers; hence, increasing the revenues and profitability. Therefore, if the owners of The New Bank's open their operations in the United Kingdom, they are more likely to make increasing profits in the subsequent years.

Moreover, the Bank of England allows all the commercial banks in the country to capitalise on all the legal investment opportunities without any interruptions. Therefore, if the owners of The New Bank decide to start their operations in the UK, they will not be disrupted by both the authorities and the Bank of England (especially, considering that they plan to comply fully with the British laws and regulations). Note that, availability of undisrupted and conducive working environment is key to business success.

Another reason we support investment in the United Kingdom has to do with technological advancement. That is, just like banks in other developed nations, the British banking sector has undergone significant transformations. Firstly, banks do not have to open branches in every corner of the country as it used to be. Instead, they simply install ATM machines and embrace digital banking systems. Doing so has reduced the time for providing services, plus it cuts the costs for opening branches in every street across the country. Also, it has reduced the number of employees; thus, reducing operating costs. Therefore, if The New Bank's owners decide to invest in the United Kingdom, they cut their operational cost; hence, improving their profit share.

The final reason we support investing in the United Kingdom concerns the country's system of governance. That is, the United Kingdom is among the nations with an advanced democratic system of leadership. As a result, British citizens are always given the opportunity to elect the leaders of their choice to represent their interests. Consequently, the chances of civil conflicts (as the ones experienced in the developing countries) erupting In the United Kingdom are very minimal. In short, the UK has a stable system of governance, which favours business operations, since investors prefer to venture their resources in countries with stable governments as it reduces the likelihood of losing their wealth to civil conflicts. Plus, democratic governments cannot snatch away assets of private investors unless they violate the law. Therefore, if the owners of The New Bank decide to operate in the United Kingdom, they will never lose their wealth to the government for no good reason. Additionally, they will have a peaceful environment to undertake their business. 


\section{The List of Assumptions about the Client}

Our bank is one of the largest banks in United Arab Emirates with net worth about $£ 1.7$ trillion. the company intends to use a lot of capital in either establishing a subsidiary or acquiring a bank in the country to increase its portfolios globally as there is high interest from local investor to invest in UK.

Firstly, the bank will issue mix of Basil III complaint debt and retain earnings, so the plan should ensure that the country intending to invest must be free from any probable risks that may affect its overall business operations such as war.

Secondly, the New Bank will be a universal bank, serving both the retail and the wholesale clients. Among the retail services that will be provided to the small-scale clients include issuing loans, honouring checks, accepting savings, opening accounts, offering small mortgage services, among others. The wholesale customers will include large clients and organisations such as real estate investors and developers, corporate clients, mortgage brokers, and international trade businesses. The New Bank will also provide banking services to institutional customers such as pension funds and health insurance program.

Thirdly, The New Bank will engage in the foreign exchange market. That is, it plans to partner with Hot Forex, a British forex broker to buy and sell the foreign currencies and cryptocurrencies. This assumption is vital for the company as it will increase its possibility of staying long in the European market. The financial institution will allow its customers to bank using majority of the country's currencies since the United Kingdom has citizens from all over the world and this will help the company in its day to day production and business operations.

Fourthly, The New Bank will run a subsidiary insurance program. That is, it plans to offer health assurance services as well as property insurance policies on risks such as fire and burglary to boost its profitability. However, much of the attention and resources will be channelled to the banking activities. In this case, the subsidiary insurance program will act as auxiliary service for its customers so that customers will be able to pay for their insurance directly from the bank without the need of withdrawing the funds and then making payments. The company assumes that this will help in retaining customers and also increasing their customer base all over the United Kingdom as they will see this aspect as an additional service for them.

Fifthly, The New Bank will be easily accessible. That is, unlike many banks that open their branches in the major cities alone, The New Bank will open branches in large and small cities so as to reach all the potential clients. However, it will not be physical branches the bank will use the new technology that new machines could interactive teller machine which preform all the function of branch. Which will help bank to reduce the overhead cost and human capital required in the physical branch. The company will ensure that their branches are widely accessible to all their client in both rural and urban centres which in this case will increase its stability and thus overall profitability for the financial institution. 
Additionally, The New Bank plans to increase efficiency in service delivery. As a result, each branch will have at least 10 fulltime employees to ensure that customers are served within the shortest time possible. Plus, it will invest a lot in the digital banking systems to reduce the customer congestions in its branches. In doing this aspect, the financial institution intends to market its business operations across the country and thus there is a need for creating online posts that will attract more customers. The company will also invest in Facebook, Twitter and Instagram as these are some of the biggest social media platforms that have many users and thus creating a greater platform for the financial institution for the increase in service delivery. This strategy will enable the bank to reach the youth generation.

Also, just as the other banks in the United Kingdom are expected to, The New Bank pledges to respect all the rules and regulations governing the banking sector and the foreign investors. For example, the bank will not participate or keep quiet on the cases of money laundering. Plus, it will pay all the taxes and license fees as required by the law. This assumption will be vital for its day to day business operations since rules and regulations that govern a particular country must be adhered to. Failure to which it may make the company lose its business operation license.

Moreover, just as other banks across the world do, The New Bank plans to embrace diversity and inclusivity in terms of offering employment opportunities and career development. For example, despite the fact that the owners are Muslim communities, they do not plan to hire the Muslims alone; instead, competent employees from various religious affiliations will be considered. Also, despite the owners being Arabs, qualified applicants from other races will be recruited without any racial discriminations. Finally, competent women will be allowed to lead different departments despite the fact that the Islamic religion (which the owners subscribe to) disputes allowing women to lead.

Finally, the owners of The New Bank plan to reinvest $70 \%$ of the bank's profit in the United Kingdom. According to them, reinvesting in the United Kingdom will not only increase their profits but also help them buy the trust of the British clients "that The New Bank is here to stay." Investing in the country will not only enhance the overall UK GDP but also increases the chances of being the biggest financial market globally.

\section{Economic Profile of the UK Focusing on Forward-Looking Projections}

\subsection{Gross Domestic Product (GDP)}

According to the international monetary fund report, the GDP of the United Kingdom will increase by $1.5 \%$ in 2018 . The rate will rise further to $1.6 \%$ in the 2019 financial year, then to $1.7 \%$ in the 2020 fiscal year. However, the IMF projects that the GDP growth rate will remain stagnant at 1.7\% in the 2021 and 2022 financial years (Imf.org, 2018). Meanwhile, the general projection depicts that the GDP of the United Kingdom will grow, which implies the economy will advance and widen; hence, increasing the aggregate demand for money (loans). Plus, the growth in GDP indicates that all sectors of the economy, including the banking sector, will also develop (Dreger and Reimers, 2013). Therefore, we recommend The New Bank's owners to invest in the United 
Kingdom since their business is more likely to grow and develop in the coming four years.

\subsection{Unemployment Rate}

According to statista.com (2018) projections, the unemployment rate of the United Kingdom will be $4.3 \%$ in the 2018 financial year. The rate will rise further to $4.4 \%$ in the 2019 fiscal year, and then shoot to $4.6 \%$ in the 2020 financial year. However, the figure will remain at $4.6 \%$ in both the 2021 and 2022 fiscal years. In general, the unemployment rate in the United Kingdom is predicted to rise. However, according to Katz (2014), the rise in the unemployment rate is not healthy for the economy and business sectors (including the banking sector) since it reduces profitability. Simply put, high unemployment implies that people do not earn sufficient income; consequently, their demand for products and services such as mortgage declines, which eventually, reduces banks' revenues and profits. Therefore, based on unemployment projections, The New Bank should not invest in the United Kingdom since it is more likely to experience declining profits in the coming years.

\subsection{Interest Rate}

According to the UK Office for Budget Responsibility (OBR) projections, the United Kingdom's interest rate will be $0.8 \%$ in 2018 financial year. The rate will rise further to $1 \%$ in 2019 fiscal year, then to 1.25\% in the 2020 financial year (Obr.uk, 2018). In the 2021 fiscal year, the UK's bank rate will rise to $1.4 \%$, before finally hitting $1.5 \%$ in 2022 financial year. Generally, the UK's bank rate will rise in the coming years, which is healthy for the players in the banking sector. According to De Grauwe (2018), the rise in interest rate increases the bank earnings from loans; hence, increasing their profitability. Therefore, based on the forecasts of the interest rate, we urge The New Bank's owners to invest in the United Kingdom since they are likely to record increasing profitability in the coming four financial years.

\subsection{Inflation}

Based on the (Bankofengland.co.uk, 2018) report, the inflation rate in the United Kingdom will be $2.74 \%$ in the 2018 financial year. The rate will reduce further to $2.16 \%$ in the 2019 fiscal year, and then to $1.95 \%$ in the financial year 2020. However, the United Kingdom's inflation rate will remain at 1.95\% in the 2021 and 2022 financial years. In overall, the inflation rate of the United Kingdom will decrease in the coming four years, which has both positive and negative effects on the players in the banking sector. In the positive side, low inflation results in low costs of products and services (including employees' salaries and wages); hence, banks make more profits due to reduced cost of productions (De Grauwe, 2018). On the contrary, low inflation makes products and services affordable to many people; consequently, the interest rate, as well as the number of people seeking bank loans to finance their purchases decline, which eventually reduces the banks' profits. Compared to the positive effects, the negative impacts of declining 
inflation rate are quite higher. Therefore, based on the forecast on the inflation rate, we discourage The New Bank's owners from investing in the United Kingdom.

\subsection{GDP Per Capita}

According to Worldbank.org (2018) report, the GDP per capita of the United Kingdom will be $£ 33,574.9$ in the 2018 financial year. The figure will rise to about $£ 34,365.3$ in the 2019 financial year, and then to $£ 35,311.4$ in the 2020 fiscal year. In 2021, the GDP per capita of the United Kingdom will rise to around $£ 36,348.5$, before finally, hitting $£ 37,583.4$ in 2022 financial year. In general, the United Kingdom's GDP per capita will increase in the coming four fiscal years, which is healthy for the banking sector. According to Robert et al., (2014), an increase in GDP per Capita implies that the major sectors of the economy are highly productive and profitable, which include the players in the banking sector. So, based on the GDP per capita projections, we recommend The New Bank's owners to venture in the United Kingdom since the chances of growing in the coming years are high.

\subsection{Population}

According to Zheng (2018), the population of the United Kingdom will be about 66.47 million by the end of 2018. The figure will rise to around 66.85 million by the end of 2019, and then to 67.18 million in 2020. In 2021, the general population of the United Kingdom will rise to around 67.48 million before finally hitting 67.75 million in 2022 financial year. Based on the figures above, the United Kingdom Population will increase in the coming four years, which is favourable for the banking sector. According to Coale and Hoover (2015), an increase in the population size in an economy implies a rise in the number of potential customers; hence, increasing profitability. Therefore, based on the population forecast, we recommend The New Bank's owners to invest in the United Kingdom.

\subsection{Balance of Trade}

Based on Worldbank.org (2018) report, the trade balance of goods and services of the United Kingdom has been fluctuating in the deficits over the last decade. Based on the records, it is more likely that the trend will prevail in the coming years. According to King (2013), the deficit balance of goods implies that the country imports more than it exports; hence, reducing the market for domestic products and services. This trend will favour The New Bank especially if you acknowledge the fact that it intends to lend large companies that deal in imports and exports. Plus, it will be dealing in forex market (helping the importers and exporters to exchange British Pound with Euro and USD). Therefore, we suggest that The New Bank should open its doors in the United Kingdom.

\subsection{Recommendation}

After analysing various economic indicators, we strongly advise The New Bank to invest in the United Kingdom since the economic opportunities in the country exceed the threats. 


\section{The Analysis of the Structure of the United Kingdom Banking Structure and Regulations}

The United Kingdom's banking system falls under "restricted universal" category since commercial banks are barred from owning commercial concerns. The major players in the United Kingdom banking sector include HSBC, the Royal Bank of Scotland Group, HBOS and Barclays bank. These banks and others focus mainly on wholesale and retail clients. However, some engage in other investments like insurance subsidiaries. Meanwhile, the following are the key aspects that can be used to analyse the United Kingdom's banking structure and regulation.

\subsection{Building Societies Act, 1986}

The Building Societies Act, (1986) encouraged many Building societies to transform to commercial banks since it prevented them from takeovers (by the already established banks) for five years. However, after the five-year period, most of those Building Societies were eventually bought by the established banks. For example, in 2000, Barclay bank bought Northern Rock and Woolwich Building Societies. Meanwhile, the retail banking/finance in Britain has a strong history with the Building societies. That is, a majority of small-scale earners deposited their savings in various Building Societies, which they would withdraw whenever they wanted to purchase homes and buildings. Today, however, Britons who want to buy homes go for mortgages in commercial banks. The following are some of the activities that the Building Societies-turned-banks were privileged to do by the Building Societies Act, 1986. Firstly, they could honour transactions made through cheques and credit card. Secondly, they could provide personal loans. Thirdly, they could engage in foreign exchange. Next, they could provide investment management advice to their clients. Fifthly, they could participate in stockbroking. They could also provide and underwrite insurance services. Additionally, they could engage in real estate business. Most importantly, they could expand and open branches in other European Union countries.

However, the Act set two conditions that all Building Societies-turned-commercial banks were to comply with. Firstly, $90 \%$ of their assets were supposed to be in form of wholesale money and resident mortgage. Secondly, the total deposits were not supposed to surpass $20 \%$ of their total liabilities. However, the rate was letter raised to $40 \%$, and then to $50 \%$.

\subsection{Regulations}

The Bank of England regulates the operations of the commercial banks in the United Kingdom. For example, the bank rate and major decisions concerning the monetary policy are made by the Bank of England. As a result, the Bank of England has the right to revoke all the banks that involve in unethical acts such as money laundering. However, Banks are free to engage in all legal investment opportunities without any interruptions (Bankofengland.co.uk, 2018). That being the case, we suggest the owners of The New Bank should invest in the United Kingdom since they will not be disrupted by both the 
authorities and the Bank of England (especially, considering that they plan to comply fully with the British laws and regulations).

\subsection{Changes in the British Retail Banking Sector}

Just like banks in other developed countries, the British banking sector has undergone significant transformations. Firstly, decades back, operating the United Kingdom banking industry required opening a lot of branches across the country. However, with technological advancement, banks have capitalized on ATM machines and digital banking which have reduced the need for opening branches in every street. According to Statista.com (2018) report, over 63\% of British citizens use digital (mobile phones, internet, among others) platforms to access banking services. As a result, each bank has adapted by laying down the necessary infrastructure for using digital banking. That is a positive transformation since it reduced the time for accessing/providing services, plus it cuts the costs for opening branches in every street across the country. Therefore, we recommend The New Bank to invest in the United Kingdom since it will incur comparatively lower operational costs.

The United Kingdom's banking sector has also experienced a rising rate of online transactions, which has significantly reduced the need for the banks. For example, a person can earn his/her salary via Skrill, and then use it to pay all his/her bills without having to withdraw cash from the bank. That, however, is a setback for the players in the banking sector since the reduction in the number of clients who use banking services has reduced their revenues and profitability. Therefore, based on the increasing rate at which British citizens are replacing banking transactions with online ones, we discourage The New Bank's owners from investing in the country. That is because the chances of their profits to increase in future are minimal.

\subsection{Competition in the UK Banking System}

Just like in other countries, the United Kingdom's banking sector is highly competitive, but with only a few banks dominating the market share. According to Economicsonline.co.uk (2018) report, Barclays and RBS banks occupy the largest segment of the market share (25.64\% each). HSBC follows with $17.09 \%$, then Santander with $14.25 \%$. The rest hold less than $10 \%$ of the market share. One of the reason banks like Barclays dominates the United Kingdom market has to do with their area and period of operations. Barclays has been operating in multiple countries across the world for decades, which increased its influence and necessary experience to compete favourably. However, a report by Cruickshank (2018) revealed that big native banks such as Barclays bank are given special treatment by the authorities and the Bank of England. That is, they are more protected from aggressive competitions than small external-owned banks. Therefore, based on the competition analysis, we discourage The New Bank's owners from investing in the United Kingdom because of two reasons. Firstly, the United Kingdom banking sector is highly competitive which will reduce The New Bank' revenues and profitability. Secondly, the bank of England is believed to favour native- 
owned banks more than the foreign ones, which means The New Bank will not receive sufficient protection from aggressive competitions.

\subsection{Recommendations}

Based on the analysis of the British Banking structure and regulation, we are indifference about whether or not The New Bank's owners should invest in the United Kingdom( this is not grammatically correct) since the magnitude of the threats and opportunities on investing the country are equal.

\section{An Analysis of Political Risks in the United Kingdom}

First of all, political risk analysis is the assessment of the likelihood that political phenomena, conditions or decisions will significantly impact the performance and profitability of a business in a particular region. Political risks can be low or high. Meanwhile, the political risk of the United Kingdom will be analyzed in the following perspectives.

\subsection{System of Governance}

The United Kingdom is among the nations with an advanced democratic system of leadership. That means that the leaders are chosen by the people to serve their interests. As a result, the chances of civil conflicts (as the ones experienced in the developing countries) happening In the UK are very minimal. Simply put, the United Kingdom has a stable system of governance, which favours business operations. According to Keynes (2017), investors prefer to invest in countries with stable governments since the chances of losing their investments to civil conflicts are minimal. Plus, democratic governments cannot snatch away assets of private investors unless they violate the law. Therefore, based on the system of governance, the United Kingdom is less risky, and so, we recommend The New Bank's owners to invest in the country.

\subsection{Brexit}

The decision for the United Kingdom to exit the European Union was politically motivated just as much as it was economically driven. Note that political decisions have both political and economic repercussions (Ramiah, 2017). Simply put, some of the benefits that the United Kingdom-based businesses used to enjoy when the country was a full member of the EU will gradually decrease as Britain completes all the steps to leave the world's leading regional economic bloc. For example, the German and French businessmen and women who used to travel freely in and out of the United Kingdom will reduce their trips since they now have to apply for passports and visas. As a result, the number of potential clients accessing the British market will decrease; hence, reducing the revenues and profitability of the United Kingdom-based businesses, including banks. Still on the issue of Brexit, some of the goods and services that the British banks used to acquire at cheaper prices from the members of the European Union will now be taxed. As a result, their prices will increase; hence, increasing the operating costs and reducing 
their profitability. Also, since Brexit basically means that the United Kingdom wanted to cut her association with the European Union, the affected countries may respond by imposing harsh restrictions against the United Kingdom exporters. As a result, the British firms that focus primarily on the European market will reduce their productions; hence, reducing the need to borrow loans. Eventually, the profitability of the British banks that depend mainly on those exporters, and those that engage in forex trade, will decline. Therefore, based on the risks surrounding the whole issue of Brexit, we urge The New Bank not to invest in the United Kingdom.

\subsection{Whether or Not Scotland Will Secede}

Although the majority of the Scotland population support and embrace being part of the United Kingdom, their leaders claimed that majority of the citizens were against the Brexit (Carrell, 2018). That means that they were compelled to receive the consequences (of Brexit) which they did not deserve. Simply put, there is some likelihood that a few radical groups/leaders in Scotland may come up again with the seceding motion to separate Scotland from the rest of the United Kingdom. If that happens, the number of clients in the United Kingdom will decline; hence, reducing the revenues and profitability of the United Kingdom-based banks. However, the chances of that happening are very minimal. Therefore, based on the analysis of whether or not Scotland will secede, we will advise The New Bank to invest in the United Kingdom since the chances of that happening are very small.

\subsection{Diplomatic Conflict with Russia}

Following the alleged incident of the Russian government poisoning her spy and his daughter in the British Soil, the United Kingdom and Russia have not been in their best diplomatic relationship (Landale, 2018). The issue has not yet been resolved fully and may escalate to economic sanctions. If that happens, the United Kingdom export to Russia will decline, as well as the number of potential Russian investors in the country will decrease. As a result, the revenues and profitability of the banks that focus mainly on companies that depend primarily on the Russian market will decline. The British banks would also sacrifice a lot of profits when potential Russian entrepreneurs are forced to exit Britain. Therefore, based on risks associated with the United KingdomRussia diplomatic ties, we discourage The New Bank's owners from investing in the United Kingdom. Additionally, the recent threats by the Russian government is another risk that may inhibit the international bank from setting up its subsidiary the country. This aspect forms a big risk that may affect the company operations in the country and thus not recommended to enter into the market.

\subsection{British Stance on Terrorism, Peace, and Human Rights and Democracy}

The British government has/is very much determined to end terrorism, promoting peace in countries like Syria, promoting human rights and democracy around the world. For example, the United Kingdom was among the nations that criticised the decision of the Syrian government to attack its citizens with poisonous gas (The Straits Times, 2018). The 
British government also promotes issues like gender equality and same-sex rights around the world. As a result, the potential investors around the globe who feel insulted by the British stance have considered her an enemy; hence, they are more likely to cut all business deals with the United Kingdom. If that happens, the number of foreign investors will reduce; consequently, the British banks will lose potential earnings from the clients that they would otherwise benefit from. However, the chances of that whole issue happening are minimal; therefore, we urge The New Bank to invest in the United Kingdom.

\subsection{Recommendation}

Based on the analysis of all the political risks surrounding the United Kingdom, we support the decision to open The New Bank in the country since the benefits supersede the costs. This decision is logically taken for a number of reasons. Firstly, according to the international monitory fund report, the GDP of the United Kingdom will increase from the financial year 2018 through the financial year 2022. The economy will advance and widen. Plus, the growth in GDP indicate that all sector in economy including the banking sector will also develop. Secondly, according to the UK office Budget Responsibility (ORB) projections, the UK interest rate will rise in the coming four financial years that will surely be reflected on the increase of profitability. Thirdly, the inflation rate in the UK will decrease in the coming four years, which has positive effects on the banking sectors because inflation rate leads to low costs of products and services. Additionally, the GDP per capital of the UK rise in the coming four fiscal years which is healthy for banking sector to be highly productive and profitable. More importantly the population of the UK will increase in the coming four years, which is favourable to the banking sector this means that the number of will increase. Moreover, the bank of England allows all the commercial banks in the country. Another reason that encourage investing in the UK is the advancement in technology. Besides, the most important reason encourage investment in the UK is the country's system of governance that is a democratic system of leadership that does not hinders private investors unless they violate law.

\section{Conflict of Interest Statement}

The authors declare no conflicts of interests.

\section{About the Authors}

Hussein Ahmad Bataineh is working in Banking sector since 2016. He has a good knowledge in different departments in Banking sector. Regarding to the education, he got MSC in Banking and Finance Bangor University (United Kingdom) Master of Science Banking and Finance in July 2019, achieving an average total mark of $76 \%$, with a degree classification: Distinction. BSC in Finance Bachelor's degree in Finance from University of Jordan January 2016. During his education and carer journey he was awarded: 1. Academic excellence certificate from Bangor University 2. Award from United Nations Relief and Works Agency (UNRWA) for effective participation in helping Syrian refuges. 
Sulaiman Al Harthy is passionate and inspiring Central Banker \& Senior Islamic banking Analyst with a solid background and first-class technical skills in Islamic Finance and Shari'a. His experience at the Central Bank of Oman over 10 years, has equipped him with the necessary skills in formulating rules and regulations, including amendments to Banking Law, and Islamic Banking Regulatory Framework (IBRF) and part of the High Shair'a Supervisory Authority secretary. As regulator in Oman working to Strengthening and enforcing legal, regulatory rules and Shari'a compliance framework for Islamic Banking Entities (IBEs) in line with best practices. Sulaiman formerly worked at Ernst \& Young in advisory services as team member of the Project Management Office PMO for the establishment of first Islamic bank in Oman, and then he moved to the Capital Market Authority in Oman regulating the Insurance sector where he monitored to conversation of first conventional insurance company to Takaful. Sulaiman is also active member of the IFSB Arabic Editing committee, and part-time lecturer at College of Banking and Financial Studies in Oman. Sulaiman earned high academic qualifications including MSc in Islamic Banking and Finance from Bangor University UK, and Bachelor of Science in Finance. Besides, he is Certified Shari'a Adviser and Auditor by AAOIFI.

Raqiya Ali Al Balushi helds various positions in Bank Muscat with the Internal Auditor position as the latest one. He had worked in the human resources department, which provided me knowledge on human behaviour. He is interested in fully grasping the best approaches in interacting with employees to harness them potential, promote their growth, and make them assets of the organization. As an internal auditor, he understands the financial aspect of the business operation with a perspective of human resources management to align the capital and the workforce. He is working as an internal auditor since 2015. In between responsibilities in Bank Muscat, he pursued my Master's degree in banking and finance from Bangor University in the United Kingdom with Distinction. The experience enriched knowledge in audits, control points, deviations, and action plans. He conducted special audits and investigations on request of the senior management or the Board of Directors. Sulaiman Al Harthy: Senior Islamic Banking Analyst at Central Bank of Oman.

Ahmad Omar Albesisi is a Bachelor of Science in Finance holder from King Abdulaziz University, Saudi Arabia in 2015. For more academic growth sought higher education in the United Kingdom and graduated with 2:1 honors in MSc Islamic Banking and Finance from Bangor University "2019". In the beginning of 2020 started his career in the largest Islamic bank "Al Rajhi Bank" as Graduate development programme and currently working as an internal auditor in the same organization.

\section{References}

Bankofengland.co.uk. (2018). The labour market and pay. [online] Bankofengland.co.uk. Available at: https://www.bankofengland.co.uk/inflation-report/2018/august2018/the-labour-market-and-pay [Accessed 7 Nov. 2018]. 
Carrell, S. (2018). Scottish parliament decisively rejects EU withdrawal bill. [online] the Guardian. Available at: https://www.theguardian.com/politics/2018/may/15/scottish-parliamentdecisively-reject-eu-withdrawal-bill-brexit [Accessed 7 Nov. 2018].

Coale, A. J., \& Hoover, E. M. (2015). Population growth and economic development. Princeton University Press.

Cruickshank, D. (2018). [online] Vocalink.com. Available at: https://www.vocalink.com/media/1603/cruickshank report 2000.pdf [Accessed 7 Nov. 2018].

De Grauwe, P. (2018). Economics of monetary union. Oxford university press.

Dreger, C., \& Reimers, H. E. (2013). Does euro area membership affect the relation between GDP growth and public debt?. Journal of Macroeconomics, 38, 481-486.

Economicsonline.co.uk. (2018). UK Banks - understanding the structure of banking. [online] Economicsonline.co.uk. Available at: http://www.economicsonline.co.uk/Business economics/Banks.html [Accessed 7 Nov. 2018].

Imf.org. (2018). [online] Available at: https://www.imf.org/external/datamapper/NGDP RPCH@WEO/OEMDC/ADVE C/WEOWORLD/GBR [Accessed 7 Nov. 2018].

Katz, L. (2014). Long-term unemployment in the Great Recession. Members-only Library. Keynes, J. M. (2017). The economic consequences of the peace. Routledge.

King, J. L. (2013). Balance of Trade in the Marketplace of Ideas. Journal of the Association for Information Systems, 14(4), 192.

Landale, J. (2018). What now for UK and Russia after spy row?. [online] BBC News. Available at: https://www.bbc.com/news/uk-43318103 [Accessed 7 Nov. 2018].

Obr.uk. (2018). Interest rates - Office for Budget Responsibility. (2018). Retrieved from https://obr.uk/economy categories/interest-rates/.

Ramiah, V., Pham, H. N., \& Moosa, I. (2017). The sectoral effects of Brexit on the British economy: early evidence from the reaction of the stock market. Applied Economics, 49(26), 2508-2514.

Robert, C., Kubiszewski, I., Giovannini, E., Lovins, H., McGlade, J., Pickett, K. E., ... \& Wilkinson, R. (2014). Time to leave GDP behind. Nature, 505(7483).

Statista.com (2018). Penetration of online banking in Great Britain from February 2014 to May 2017, by device. Retrieved from https://www.statista.com/statistics/289081/penetration-of-online-banking-ingreat-britain-by-device/

Statista.com. (2018). Forecasted unemployment rate UK 2016-2022 I Forecast. Retrieved from https://www.statista.com/statistics/374800/unemployment-rate-forecast/

Statista.com. (2018). Forecasted unemployment rate UK 2016-2022 I Forecast. [online] Statista. Available at: https://www.statista.com/statistics/374800/unemploymentrate-forecast/ [Accessed 7 Nov. 2018].

The Straits Times. (2018). US, UK, France strike Syria to punish Assad for suspected poison gas use. [online] Available at: https://www.straitstimes.com/world/middle-east/us-uk- 
france-strike-syria-to-punish-assad-for-suspected-poison-gas-use [Accessed 7 Nov. 2018].

Worldbank.org. (2018). GDP Per Capita. [online] Available at: https://data.worldbank.org/indicator [Accessed 7 Nov. 2018].

Worldbank.org. (2018). Trade in services. [online] Available at: https://data.worldbank.org/indicator/BG.GSR.NFSV.GD.ZS [Accessed 7 Nov. 2018].

Zheng, Y. (2018). National Population Projections - Office for National Statistics. [online] Ons.gov.uk. Available at: https://www.ons.gov.uk/peoplepopulationandcommunity/populationandmigrati on/populationprojections/bulletins/nationalpopulationprojections/2016basedstati sticalbulletin [Accessed 7 Nov. 2018]. 
Hussein Ahmad Bataineh, Sulaiman Humaid Al Harthy, Raqiya Ali Al Balushi, Ahmad Omar Albesisi COUNTRY RISK ASSESSMENT FOR THE UNITED KINGDOM

Creative Commons licensing terms

Authors will retain copyright to their published articles agreeing that a Creative Commons Attribution 4.0 International License (CC BY 4.0) terms will be applied to their work. Under the terms of this license, no permission is required from the author(s) or publisher for members of the community to copy, distribute, transmit or adapt the article content, providing a proper, prominent and unambiquous attribution to the authors in a manner that makes clear that the materials are being reused under permission of a Creative Commons License. Views, opinions and conclusions expressed in this research article are views, opinions and conclusions of the author(s). Open Access Publishing Group and European Journal of Economic and Financial Research shall not be responsible or answerable for any loss, damage or liability caused in relation to/arising out of conflict of interests, copyright violations and inappropriate or inaccurate use of any kind content related or integrated on the research work. All the published works are meeting the Open Access Publishing requirements and can be freely accessed, shared, modified, distributed and used in educational, commercial and non-commercial purposes under a Creative Commons Attribution 4.0 International License (CC BY 4.0). 